\title{
Evaluation of the Raphanus Sativus Varieties Response to the Application of Dinitrophenol in Terms of Oxidative Stress Enzymes and DNA Amplification
}

\author{
ELENA TODIRASCU - CIORNEA ${ }^{1}$, ELENA GROSU², GABRIELA DUMITRU1*, DIANA BUCUR², LUCIAN GORGAN ${ }^{1}$ \\ ${ }^{1}$ Alexandru Ioan Cuza University of lasi, Department of Biology, 20A Carol I Blvd., 700506, lasi, Romania \\ ${ }^{2}$ Biological Researches Institute Stejarul, 6 Alexandru cel Bun, Str., 610004, Piatra Neamt, Romania
}

\begin{abstract}
The oxidative stress at the vegetable organisms represents a complex chemical and physiologic phenomenon which appears as a result of the different influence of biotic and abiotic stressor factors, the negative strong impact of these ones being due to the massive superproduction and to the accumulation of the oxygen reactive species. The present material demonstrate the dinitrophenol phytotoxicity, chemical agent which enters in composition of lots pesticides, on the Raphanus sativus var. sativus species viability, the München Bier and French Breakfast varieties cropped in lab conditions through antioxidant enzymes' activity modifications, but also to those appeared at the genome's level.
\end{abstract}

Keywords: 2,4-dinitropfenol, Raphanus sativus, oxidative stress, DNA

The radish (Raphanus sativus L.), species from the Brassicaceae family, is one of the most used vegetable cultivations for the human input especially in the EastEuropean and Asiatic countries [1]. This species contains alcaloids and nitrates compound, coumarins, enzymes, giberelines, glucozinolats, organic acids, phenolic compounds, pigments, polyzaharides, proteoglicans and sulfuric compounds with role in the antimicrobial's, antioxidativ's, antitumoral's and antiviral's activity increasing, acting as antagonists of the calmoduline's, inhibitors of growing, anti-hipotensivs - agents etc. [2]. Also, the compounds presence as the catechine, the siringic acid, the vanilic acid, the ferulic acid, the sinapic acid, the 0 -coumaric acid, the miricetine and the quercitine offers to the radishes antioxidant properties [3]. In the same time, the radish presents a high nutritional value being significant rich in vitamins of the ascorbic acid type and of the vitamins B complex, carotenes, proteins, carbohydrates, fibers and mineral salts [4,5]. The richness in antioxidant enzymes and other bioactive compounds $[6,7]$, confers to this species hepatoprotective effects, antiinflamatory and chemopreventive [8,9].

The aim of this study was to evaluate the biochemical and genetic answer of two varieties of Raphanus sativus var. sativus (French Breakfast and München Bier) at the treatment with 2,4 - dinitrophenol (DNP).

\section{Experimental part}

Biological material

The study was realized on two types belonging to Raphanus sativus var. sativus species namely French Breakfastand München Bier cropped in lab conditions. The seeds were put on germination in 16 flowerpots tagged, with the diameter of $13.5 \mathrm{~cm}$, using tablets of black peats with the diameter of $3 \mathrm{~cm}$. The seeds germination took place at 5 days since the insemination, and the young plants were soaked with a constantly volume of water, once every three days. When the plants reached the high of $7 \mathrm{~cm}$, in parallel with the control plot, was began the apply of treatment with 2,4 - DNP of $10^{-3} \mathrm{M}$ concentration, after 30 days of treatment being harvested samples from each flowerpot in part, as well for the biochemical determinations as for those genetic. To mention is the fact that for the genetic analyze were taken, after the treatment, samples from each of those four types of the two genres from which was cropped biological material even before the treatment's debut, these ones representing the reference samples.

\section{The biochemical analyze}

The biochemical parameters taken into study were investigated through spectrophotometers methods using the UV-Vis Shimadzu 1700 spectrophotometer. Thus, the superoxid-dismutase activity (SOD; EC 1.15.1.1) was determined through the method with nitro-bluetetrazolium. The catalase (CAT; EC 1.11.1.6) was estimated through Sinha method, while the peroxidase activity (POX; EC 1.11.1.7) through the method with o-dianisidine. The total soluble proteins concentration was determined through Bradford method [10].

The obtained results were statistically processed with the help of Microsoft Excel program (t-Studenttest), being considerate significantly at values of $p$ less than 0.05 . The data were expressed as medium values on each plot \pm the standard deviation.

\section{The genetic analyze}

The study of genetic polymorphisms realized with fresh foliar tissue of Raphanus sativus through RAPD method. To isolate the total DNA from the radish leaves was used Wizard ${ }^{\circledR}$ Genomic DNA Purification Kit (Promega Corporation, USA) and the total DNA isolated quantification was realized through the usage of the ACTGene ASP-3700 spectrophotometer, the blank solution being represented by the rehydration solution of the DNA. The enlargement of RAPD of the genomic polymorph DNA isolated from Raphanus sativus plants was realized through the utilization of the Go Taq ${ }^{\circledR}$ Green Master Mix kit (Promega Corporation, USA) and of the primers: S2134, OPA06 and OPB02. The obtained products from the RAPD enlargement of the total DNA extracted from Raphanus sativus plants were migrated then through electrophoresis on agarose gel 1.5\% [11].

On the strength of the electrophoresis gels photos are made enlargement matrixes using as a mark the marker with molecular weight of $100 \mathrm{pb}$. Subsequently are 
generated similarity and dendograms matrixes, utilizing the RStudio interface (RStudio Team, 2014), in the R software (R Team) and the adegenet package [12] through methods of discrimination analyze of the main components (DAPC).

\section{Results and discussions}

\section{Biochemical parameters}

It is known, on the one hand the fact that the plants present numerous absorption tendencies of oligoelements and nutrients, these ones biodisponibility being connected by their soil's constituents, the vegetable organisms absorbing easier the substances dissolved in solutions, and on the other hand the wish to increase the production of vegetables culture lead to the usage on a more and more largely scale of the pesticides in the agriculture $[13,14]$. In the same time, the plants are adapted to survive to an excess of the different harmful substances, the DNP toxicity being taken as a derangement of the cellular metabolism, to which the plant responds through generating the oxygen reactive species (ROS).

In what concerns these ones elimination and the reestablish of the cellular homeostasis, the vegetable organisms developed in time different defense mechanisms [15] which contain the activating both of the enzymatic antioxidant systems (the superoxidedismutase, the catalase, the peroxidase, the ascorbatoxidase, the glutation-reductase and the polyphenoloxidase), as of the non-enzymatic systems (the ascorbic acid, the tocoferols, the carotenes, the polyphenols) [16]

The SOD is considerate as being the first line defense

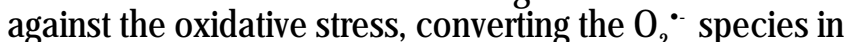
$\mathrm{H}_{2} \mathrm{O}_{2}$ [17], the activity of this enzyme at Raphanus sativus var. sativus, the München Bier genre, reaches the medium value of $7.533 \pm 0.519 \mathrm{SODU} / \mathrm{\mu g}$ protein at the control plot, while, at the variant treated with DNP the activity of this enzyme registers a maximum valoric threshold of $8.921 \pm 0.395 \mathrm{SODU} / \mu \mathrm{g}$ protein (fig. 1). At the French Breakfast genre the situation is slightly different, in the sense that maximal values were decelated at the reference variant ( $5.346 \pm 0.453 \mathrm{SODU} / \mathrm{\mu g}$ protein), the experimental plotsubdued to the DNP treatment laying a medium activity slightly decreased $(4.858 \pm 0.265 \mathrm{SODU} / \mu \mathrm{g}$ protein). Besides, some studies signalized the increase of the antioxidantenzymes activity in conditions of major abiotic stress [18] or, on the contrary, the activity's alteration of these oxidoreductases indeed as a weapon in the battle of the vegetable cell against the oxidative disaster [19].

In explaining the obtained results we must have in view the period which flowed from the moment of the beginning of the treatment apply up to the effective determination of the enzymatic activity [20], the DNP exposure period and

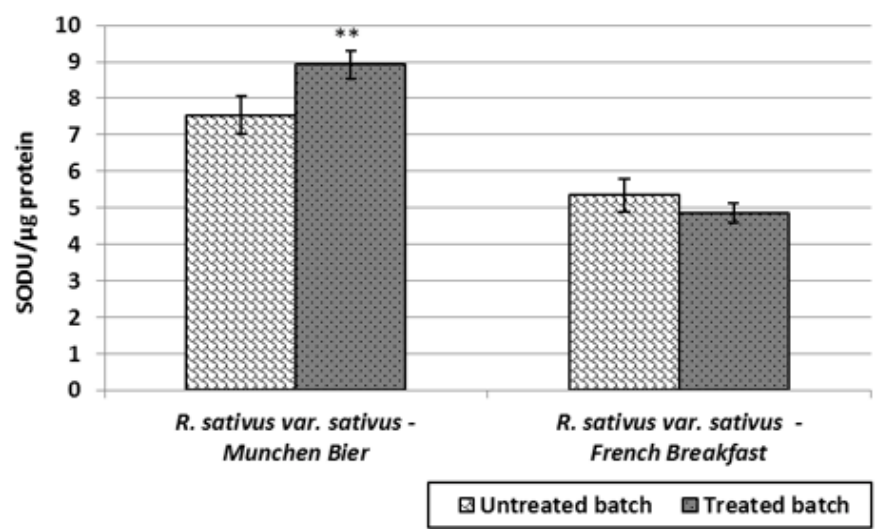

Fig. 1. SOD activity at Raphanus sativus var. sativus, genres Munchen Bier and French Breakfast the absorpted concentration by the vegetable organisms being key factors in the impact's evaluation of this agent on the plant, translated through the accumulation of the free radicals in the cell. In the same time, to retain is also the fact that the radish has a period of vegetation slightly short by comparison to other species [21,22], and the specialty literature signalize an increase slightly intense of the SOD activity on the way of the young plants' elongation of the different vegetable species [23].

The CAT is an enzyme metat the bacteria, fungi, animals and plants [24], serving to protect the cell of toxic effects of the hydrogen peroxide by its discomposing catalisation in molecular oxygen and water, without producing free radicals [25].

Our results highlight the fact that the München Bier genre (fig. 2), the DNP demonstrate its negative strong impact on the vegetable cell, the quantity of free radicals formed being high significant, thing highlighted by the catalasic activity two times higher in the sample subdued to the action of this phytotoxic compound comparatively with

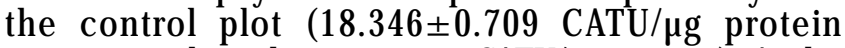

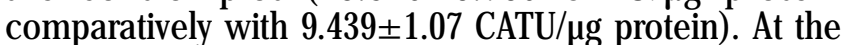
French Breakfast genre it can be observed an increase slightly moderated of the activity of this oxidoreductase after the apply of the 2,4-DNP $10^{-3} \mathrm{M}$ solution, the medium levels registered in the two plots being of $13.709 \pm 0.38$

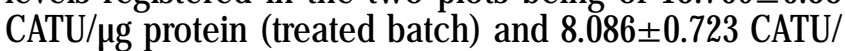
$\mu \mathrm{g}$ protein (untreated batch). The statistical analyze of the experimental data obtained reinforces the above affirmations, in the sense that at the München Bier genre the differences between the two plots are strongly significant $(p<0.001)$, while at the French Breakfast are significant $(p<0.01)$.

Furthermore, a series of researches from the domain signalized the appearance of some major disequilibrium of the metabolic reactions as a consequence to the DNP's fitotoxicity [26-28], the increase of the oxidative stress' level determining implicitly the oxido-reducting enzymes activity's increase [29].

It is known the fact that the catalases' efficiency in the $\mathrm{H}_{2} \mathrm{O}_{2}$ neutralization is more decreased than that of the peroxidases, especially in the conditions in which the substratum is found in small concentrations, the CAT being able to catalyze the direct conversion of $\mathrm{H}_{2} \mathrm{O}_{2}$ in $\mathrm{H}_{2} \mathrm{O}$ and $\mathrm{O}_{2}$, when the concentration of $\mathrm{H}_{2} \mathrm{O}_{2}$ is increased - the catalytic way, or to oxidate the substratum of the methanol, ethanol, formaldehyde, nitrite type through hydrogen peroxide intermede when $\mathrm{H}_{2} \mathrm{O}_{2}$ is in decreased concentrations - the peroxidative way [30]. Consequently, in a last series of experiments we followed the response of the two genres of Raphanus sativus var. sativus to the apply of the DNP treatment through the POX activity.

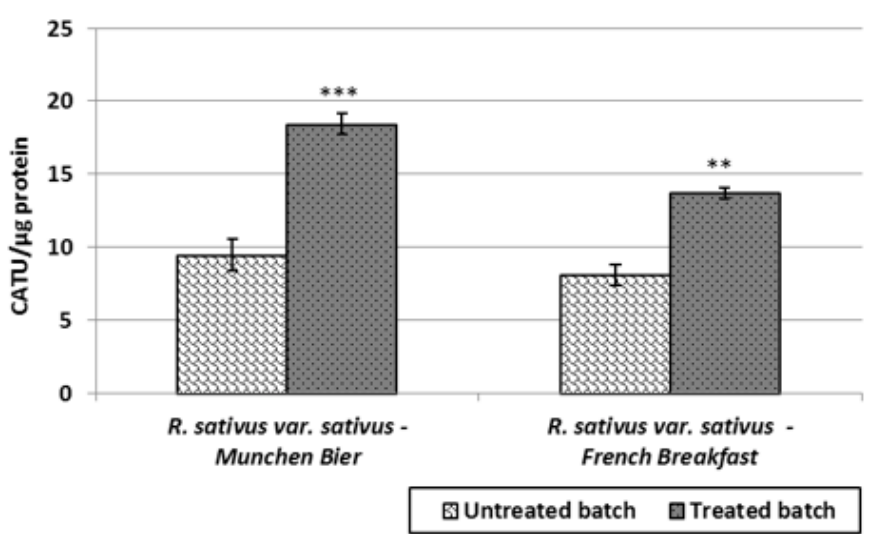

Fig. 2. CAT activity at Raphanus sativus var. sativus, genres Munchen Bier and French Breakfast 
Besides, the literature data highlighted the involvement of this hemoprotein in a large variety of physiologic and biochemic processes as the forming of the lignin and of the suberine, of the auxine's metabolism, of the cells elongation, of the phenolic oxidation etc. [31-33].

Also this time the experimental variants treated with DNP presented an increase of the POX activity - a functional enzyme which may oxidate different substratum in the $\mathrm{H}_{2} \mathrm{O}_{2}$ presence and may produce, in the same time, ROS [34]. Thus, at Munchen Bier genres the activity of this oxidoreductase reached medium values at the reference plot of $11.227 \pm 0.605 \mathrm{POXU} / \mathrm{\mu g}$ protein (fig. 3), while the samples treated with DNP registered a valoric threshold of $14.444 \pm 0.62 \mathrm{POXU} / \mu \mathrm{g}$ protein, the Student statistic signification test signalizing, besides the presence of some significant differences between the two plots studied $(0.001<p<0.005)$. In exchange, at the French Breakfast genre the apply of the treatment with DNP solution of $10^{-3} \mathrm{M}$ induced an oxidative stress more intense incarnated by the enhancement of the activity of this enzyme at the treated plot (13.534 $\pm 0.491 \mathrm{POXU} / \mu \mathrm{g}$ protein) towards the reference plot ( $7.77 \pm 0.387 \mathrm{POXU} / \mu \mathrm{g}$ protein). These affirmations are also sustained by the degree of statistical signification of our data, the differences between the two samples being, this time, strongly significant $(p<0.001)$.

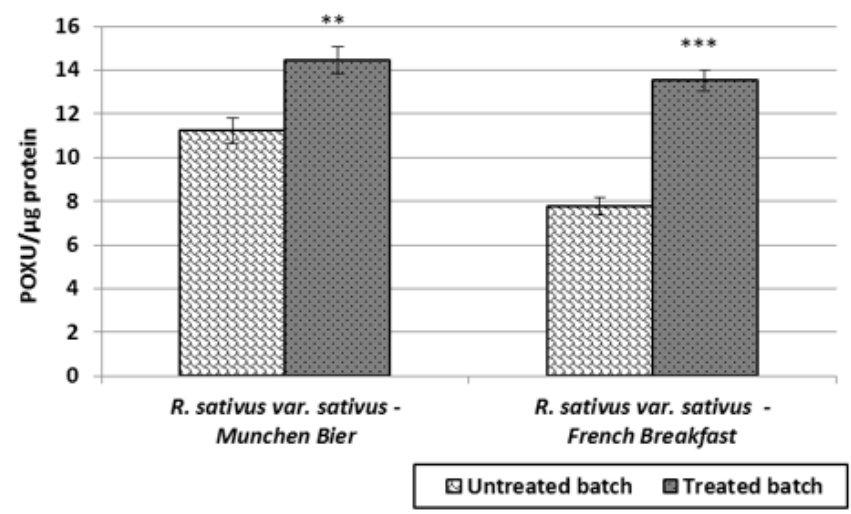

Fig. 3. POX activity at Raphanus sativus var. sativus, genres Munchen Bier and French Breakfast

\section{Genetic investigations}

From the 3 primers used only 2 presented amplifications, S2134 and OPB02. In the moment of the enlargement matrix' built was remarked that the primers amplified differently the two samples of isolated DNA from the same individual, function of the moment of samples' prelevation, before and after the apply of the treatment with 2,4-DNP, fact that can suggested that the applied treatment determines modifications in the DNA structure. In figure 4 are presented the RAPD products obtained through the total DNA enlargement with the S2134 primer. There are clearly observed differences between the two gels, in the first part of the figure $(A)$ the fragments of enlarged DNA, derived from untreated individuals, having lengths between 400 and $700 \mathrm{pb}$, while in the second part of the figure (B) it is observed that the enlarged DNA fragments length (derived from the same individuals to whom there was applied the treatment with 2,4-DNP) is between 600 and $1400 \mathrm{pb}$.

From the 8DNA samples derived from individuals before the apply of the treatment, only 3 present bands after the RAPD enlargement products' migration through electrophoresis. In what concerns the DNA samples derived from the same individuals treated with 2,4-DNP $10^{-3} \mathrm{M}$, it is observed the enlargement of the DNA fragments for each sample.

The RAPD enlargement with the OPB02 primer it may be observed in figure 5 . And in this case were enlarged DNA samples derived from the same individuals butbefore and after the apply of the treatment. There is observed the existence of some band for all samples, fact that indicates the presence of the DNA fragments with the length of 700 $\mathrm{pb}$, both before, as well as after the apply of the treatment with 2,4-DNP $10^{-3} \mathrm{M}$.

Significant differences appear in the case of samples 5 , 6 and 8 , where it is ascertained that the enlargement of total DNA, isolated after the apply of the treatment, leads to the appearance of a band that indicates the presence of some DNA fragment with the length of $800 \mathrm{pb}$. In what concerns the DNA fragment lengths, these are between 700 and $1300 \mathrm{pb}$ for the samples derived from individuals before the beginning of the treatment and between 600 and $1300 \mathrm{pb}$ for the samples emerged after the apply of the treatment.

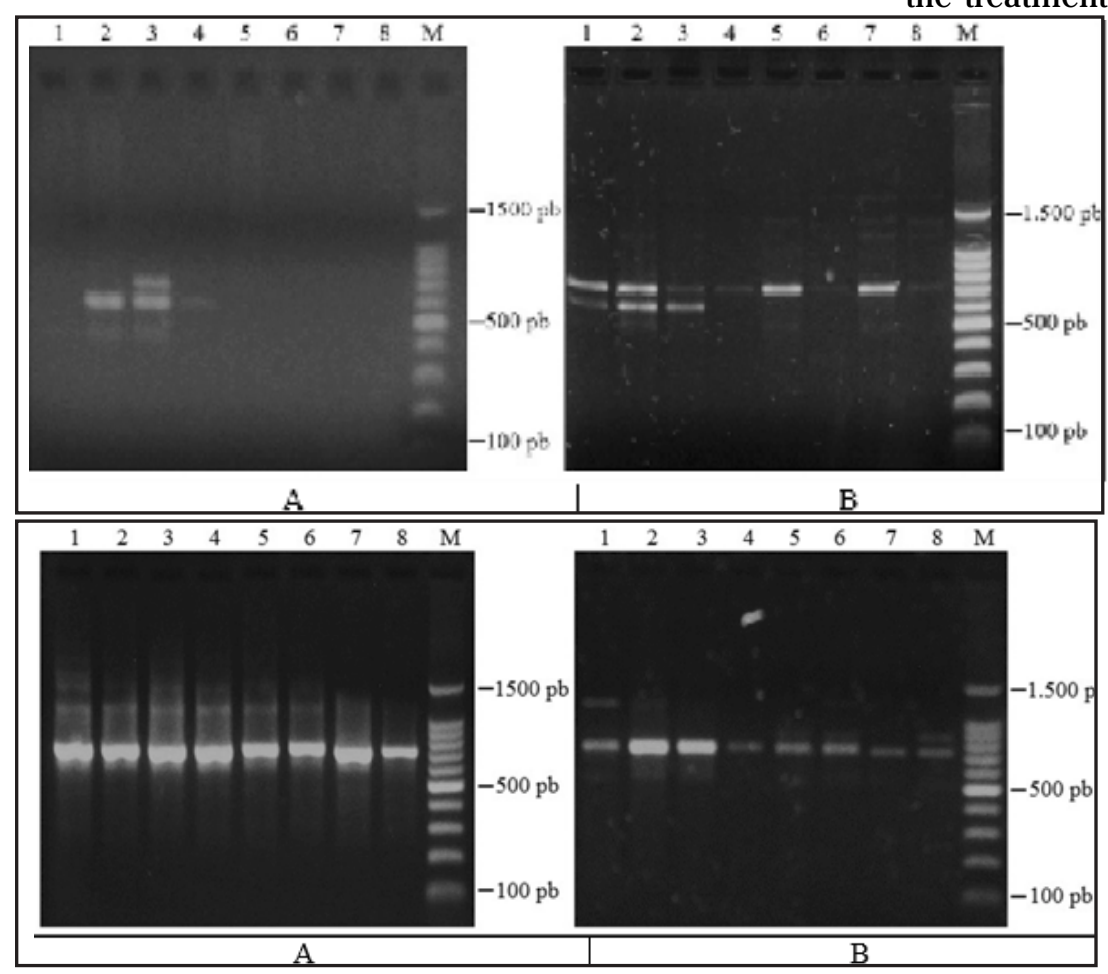

Fig. 4. RAPD products obtained with S2134 primer (A) DNA from the untreated plants;

(B) DNA from the treated plants with 2,4-DNP

Fig. 5. RAPD products obtained with OPB02 primer (A) DNA from the untreated plants; (B) DNA from the treated plants with 2,4DNP 
After the enlargement matrixes processing built on the electrophoresis gels photos, it could be ascertained the impact that has the treatment with $2,4-\mathrm{DNP} 10^{-3} \mathrm{M}$ on the individuals from the Raphanus sativus species. Considering the fact that it was worked with multiple gels and multiple bands, through the study of brute data, the samples have a random disposition within the dendrogram genetic distances (fig. 6 - A.D). By applying the function of discrimination analyze of the main compounds (DAPC) it is ascertained a divergence of the pre-treatment samples (noted with Rsfb-t and Rsmb-t) (fig. 6 - A.De).

To verify the accuracy of DAPC analyze it was studied the impact of each RAPD marker pointing out that the S2134 marker has a considerable contribution in the distribution of the samples on clusters, especially alleles 1 and 3 (fig. 6 - B.Plot1). It could be ascertained also the contribution of each main item on the samples distribution, the compound 5 having the biggest impact due to the high variability, which offers the ability of samples discrimination (fig. 6 -B.Plot2).
Through the discrimination analyze of the main compounds was generated a tree that shows the distance between the two experimental variants, pre-treatment (noted with Rsfb and Rsmb) and post-treatment (noted with Rsfb-t and Rsmb-t). It is ascertained that the applied treatment produce modifications at the level of the genetic material of the individuals, thus, through the grouping in clusters of the DNA samples emerged before and after the apply of the treatment, appear clearly differences for the same individual (fig. 7-A). The distribution of the pre- and post-treatment samples indicates that there aren't major differences between the individuals from the two genres, instead of it there is very well ascertained a differentiation between the samples derived from the individuals before the apply of the treatment (noted with Rsfb and Rsmb) and the samples derived from the same individuals to whom there was applied the treatment with 2,4-DNP 10${ }_{3} \mathrm{M}$ (noted with Rsfb-t and Rsmb-t) (fig. 7 - B).

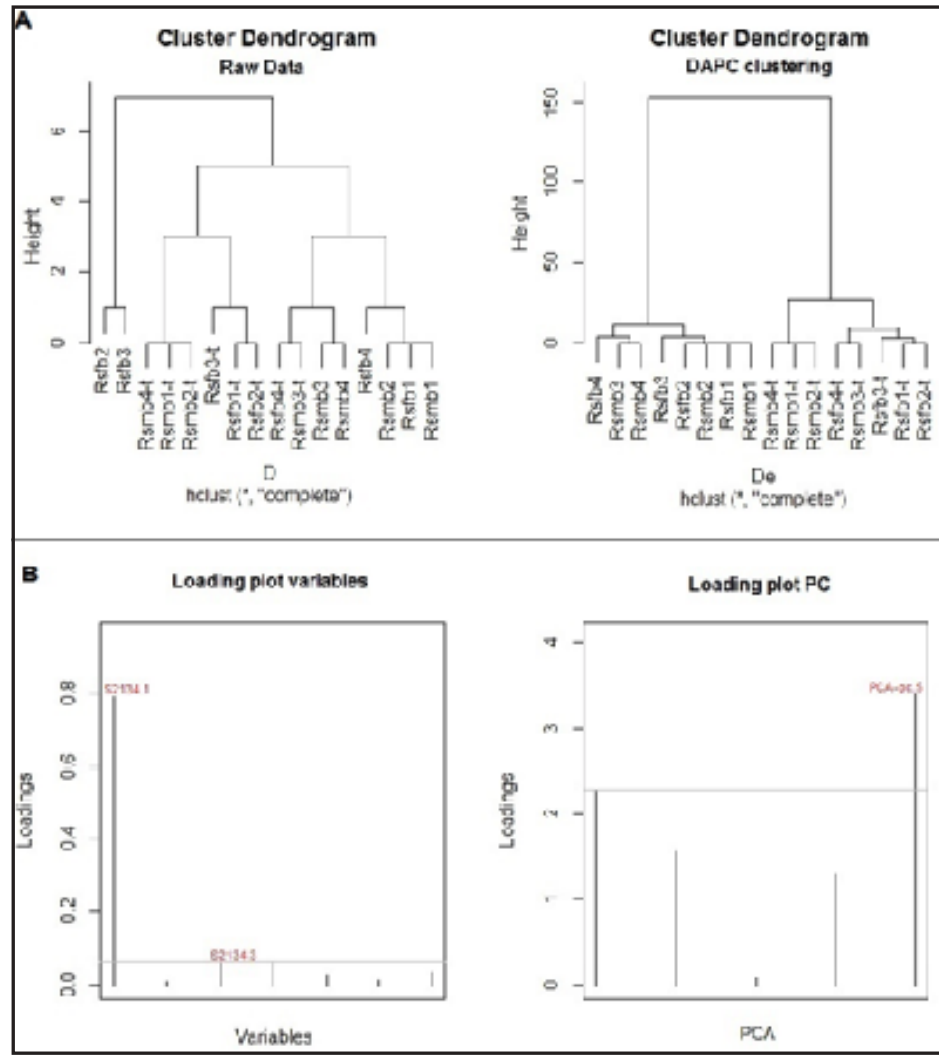

Fig. 6. The main compounds contribution on the samples distribution

\section{A}
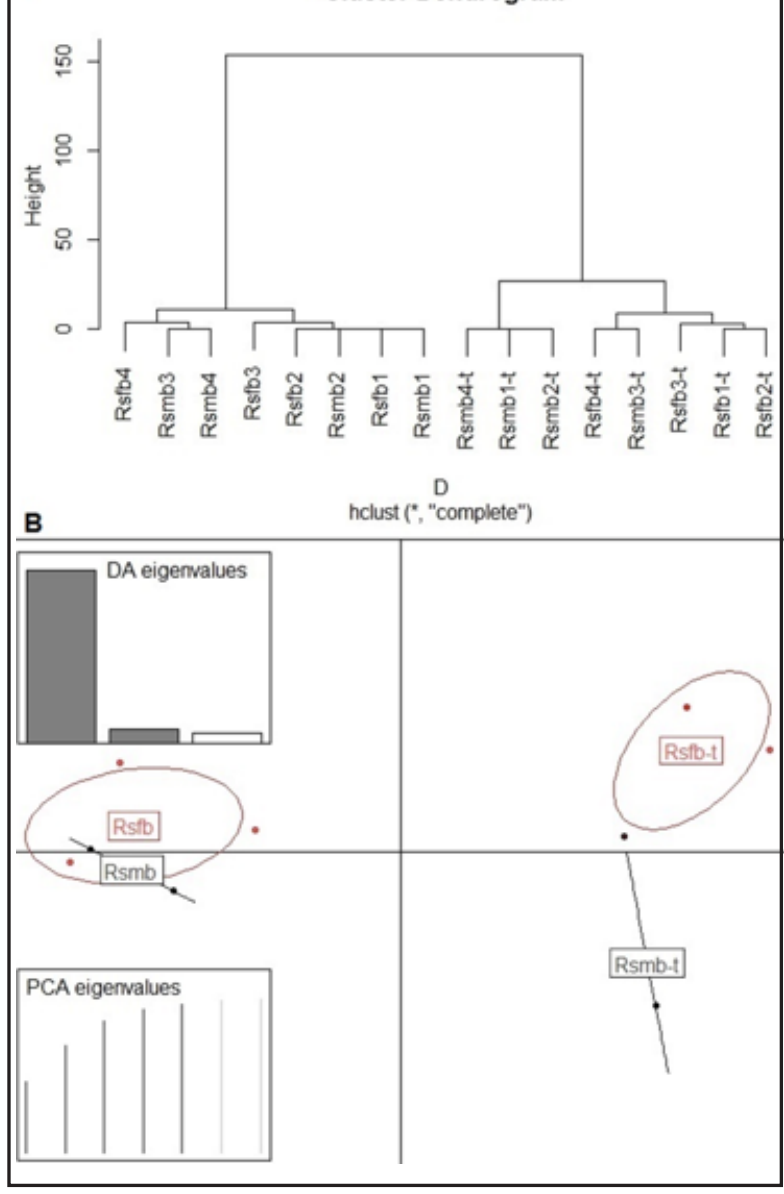

Fig.7. The discrimination analyze of the main compounds 


\section{Conclusions}

There was demonstrated the 2,4-DNP capacity to influence the production of free radicals and the installing of the oxidative stress through the activity modification of all studied antioxidant enzymes, at the München Bier genre being remarked medium valoric threshold of activity slightly significant towards the French Breakfast. The experimental results obtained highlight differences strongly significant between the two experimental variants in what concerns the CAT activity at the München Bier genre and POX at the French Breakfast genre.

The high toxicity degree of the 2,4-DNP was demonstrated through the modifications produced in the ADN structure, which consist in the apparition of the multilocus mutations, that enabled the attachment of the primers used in a higher number of sites, aspect highlighted through the apparition of new bands after the RAPD analyze and of the samples electrophoresis subdued to treatment.

For isolated DNA after the apply of the treatment, the RAPD analyze using the S2134 primer leaded to the enlargement of some new fragments with lengths up to $1400 \mathrm{pb}$, while the band specific to fragments of $400 \mathrm{pb}$ wasn't present. In the case of the OPB02 primer there was remarked the enlargement of some new fragments of 600 $\mathrm{pb}$ and $800 \mathrm{pb}$.

\section{References}

1.HAN, N.R., SU'UDI, M., KIM, J., Hort. Environ. Biotechnol., 56, nr. 2, 2015, p. 152.

2.SHIN, T., AHN, M., KIM, G.O., PARK, S.U., Orient Pharm. Exp. Med., 15, 2015, p. 105.

3.WIART, C., Medicinal plants of China, Korea, and J apan: Bioresources for tomorrow's drugs and cosmetics, CRC Press, 2012.

4.HOLLAND, B., WIDDOWSON, E.M., UNWIN, I.D., BUSS, D.H., Vegetables, herbs and spices: Fifth Supplement to McCance and Widdowson's, The composition of foods. Royal Society of Chemistry, 1991.

5.GUTIERREZ, R.M., PEREZ, R.L., Scientific World J ournal, 4, 2004, p. 811.

6.TAKAYA, Y., KONDO, Y., FURUKAWA, T., NIWA, M., J. Agric. Food Chem., 51, 2003, p. 8061.

7.KATSUZAKI, H., MIYAHARA, Y., OTA, M., IMAI, K., KOMIYA, T., Biofactors, 21, 2004, p. 211.

8.BAEK, S.H., PARK, M., SUH, J.H., CHOI, H.S., Biosci. Biotechnol. Biochem., 72, 2008, p. 1176.

9.CASTRO-TORRES, I.G., DE LA, O.A.M., GALLEGOS-ESTUDILLO, J., NARANJ O-RODRIGUEZ, E.B., DOMINGUEZ-ORTIZ, M.A., Phytother. Res., 28, 2014, p. 167.

10.ARTENIE, VL., UNGUREANU, E., NEGURA, A.M., Metode de investigare a metabolismului glucidic si lipidic, Editura Pim, lasi, 2008, p. 97, 171.
11.GORGAN, D.L., Introducere în studiul filogeniei si filogeografiei moleculare, Editura Bioflux, Cluj-Napoca, 2008.

12.J OMBART, T., Bioinformatics, 24, 2008, p. 1403.

13.SPONGBERG, A.L., GOTTGENS, J.F., MULLER, B.E., Water, Air, and Soil Pollution, 152, 2004, p. 387.

14.DURAY, B., NAGY, I., ANDRES, L., MILOŠEVIÆE, D.D., Carpath. J . Earth. Env., 10, nr. 3, 2015, p. 207.

15.MOURATO, M.P., MOREIRA, I.N., LEITÃO, I., PINTO, F.R., SALES, J.R., LOURO MARTINS, L., Int. J. Mol. Sci., 16, nr. 8, 2015, p. 17975.

16.RUCIÑISKA-SOBKOWIAK, R., Postepy Biochem., 56, nr. 2, 2010, p. 191.

17.SYTYKIEWICZ, H., PLOS ONE, 9, nr. 4, 2014, e94847.

18.TODIRASCU-CIORNEA, E., DUMITRU, G., Braz. Arch. Biol. Technol., 59, 2016, e16160299.

19.CAVERZAN, A., CASASSOLA, A., BRAMMER, S.P., Genet. Mol. Biol., 39, nr. 1, 2016, p. 1.

20.CARMAK, I., STRBAC, D., MARSCHNER, H., J. Exp. Bot., 44, nr. 1, 1993, p. 127.

21.KUTOVENKO, V., TYHA, N., MERZHIJ , N., Stiinta agricola, 1, 2014, p. 35.

22.BEIN'AN, C., MIHU, C., Research Journal of Agricultural Science, 47, nr. 2, 2015, p. 7.

23.KANG, H.M., SALTVEIT, M.E., Physiol. Plantarum, 115, 2002, p. 244. 24.DUNFORD, B., Peroxidases and catalases: biochemistry, biophysics, biotechnology, and physiology. Hoboken, New Jersey, John Wiley \& Sons, 2010.

25.CHELIKANI, P., FITA, I., LOEWEN, P.C., Cell Mol. Life Sci., 61, nr. 2, 2004, p. 192.

26.PINTILIE, O., ANDRIES, C., COSMA, A., ZAHARIA, M., DROCHIOIU, G., VASILACHE, V., SANDU, I., Rev. Chim.(Bucharest), 66, no. 9, 2015, p. 1321.

27.PINTILIE, O., ION, L., SURLEVA, A., ZAHARIA, M., TODIRASCUCIORNEA, E., CIUBOTARIU, E., BALAN, A., DROCHIOIU, G., SANDU, I., Rev. Chim.(Bucharest), 67, no. 4, 2016, p. 687.

28.TODIRASCU-CIORNEA, E., DROCHIOIU, G., STEFANESCU, R., AXINTE, E.V., DUMITRU, G., Braz. Arch. Biol. Technol., 59, 2016, e16150580.

29.CHAKRABARTY, D., VERMA, A.K., DATTA, S.K., Journal of Horticulture and Forestry, 1, nr. 6, 2009, p. 113.

30.PARVAIZ, A., Oxidative damage to plants: Antioxidant netw orks and signaling. Srinagara: Academic Press Elsevier Inc., 2014.

31.HIRAGA, S., SASAKI, K., ITO, H., OHASHI, Y., MATSUI, H., Plant Cell Physiol., 42, 2001, p. 462.

32.HU, Y., WU, J., LUO, P., MO, Y., Afr. Biotechnol., 11, 2012, p. 2752. 33.DIAZ-TIAELS, C., GRAÑA, E., REIGOSA, J.M., SANCHEZ-MOREIRAS, M.A., Plant Signal Behav., 7, nr. 10, 2012, p. 1274.

34.PASSARDI, F., PENEL, C., DUNAND, C., Trends Plant Sci., 9, nr. 11, 2004, p. 534.

Manusccript received: 15.07 .2018 